\title{
MULTI-LOCAL LIVING - AN OPPORTUNITY FOR RURAL HEALTH SERVICES IN FINLAND?
}

\author{
Olli Lehtonen¹, Toivo Muilu², Hilkka Vihinen ${ }^{3}$
}

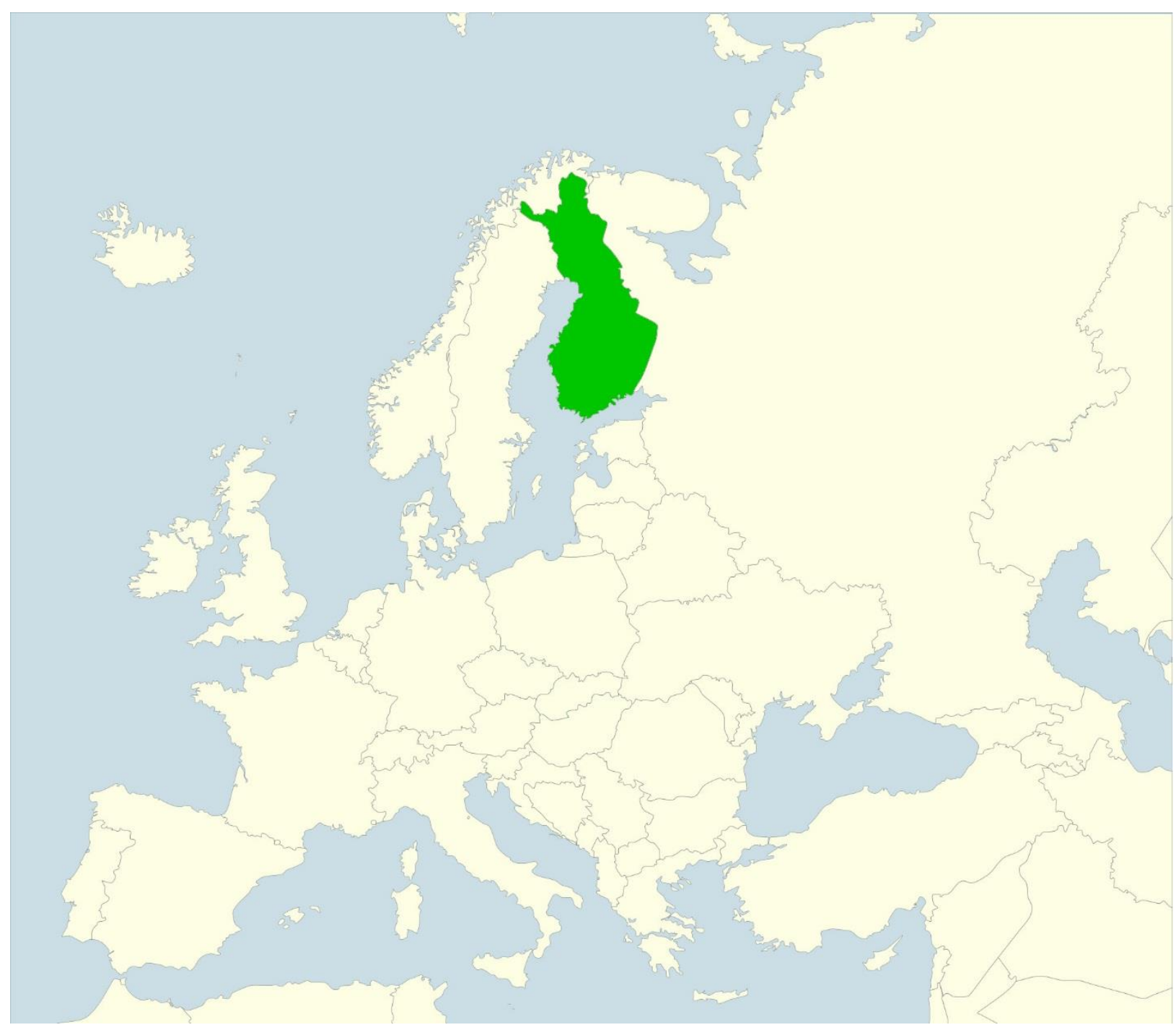

1 Olli Lehtonen, PhD, Senior Scientist, Natural Resources Institute Finland (Luke), Latokartanonkaari 9, FI-00790 Helsinki, Finland, and University of Eastern Finland, Yliopistokatu 2, FI-80100 Joensuu, Finland; olli.lehtonen@luke.fi

2 Toivo Muilu, PhD, Research Professor of Rural Research, Natural Resources Institute Finland (Luke), Paavo Havaksen tie 3, FI-90014 University of Oulu, Finland; toivo.muilu@luke.fi. ORCID: 0000-0001-7592-8506

${ }^{3}$ Hilkka Vihinen, PhD, Research Professor of Rural Policy, Natural Resources Institute Finland (Luke), Maarintie 6, FI02150 Espoo, Finland; hilkka.vihinen@luke.fi 
Abstract: In the simplest definition, multi-local living means that a person or family have more than one residence or place to stay. In Finland, multi-locality has become a common phenomenon in recent decades, but the effects of it are not yet considered in decisionmaking or planning. This is because the "invisible population" created by multi-locality is not reflected in traditional population statistics. The assumption in this article is that multi-locality would provide opportunities to improve accessibility of health and social services in rural areas. The assumption is tested in the North Kymenlaakso region, Finland. The results point to that one-stop services and mobile services are costefficient and flexible provision models for rural areas. The results call for making the increasing multi-locality in society more visible and to utilize it better than at present as a resource for the development of rural areas.

Keywords: multi-locality, health services, spatial optimization, North Kymenlaakso region, Finland

\begin{abstract}
Abstrakti: Monipaikkainen asuminen - mahdollisuus maaseudun terveyspalvelujen järjestämiseksi? Yksinkertaisimmillaan monipaikkainen asuminen tarkoittaa, että henkilöllä tai perheellä on useampia asuin- tai muita paikkoja, joissa oleskella. Suomessa monipaikkainen asuminen on yleistynyt viime vuosikymmenten aikana, mutta sen vaikutuksia ei ole vielä otettu huomioon päätöksenteossa tai suunnittelussa. Tämä johtuu siitä, että monipaikkaisuuden synnyttämä "näkymätön väestö" ei näy perinteisissä väestötilastoissa. Tämän artikkelin perusolettamus on, että monipaikkainen asuminen tarjoaisi mahdollisuuksia parantaa terveys- ja sosiaalipalvelujen saatavuutta maaseuduilla. Olettamusta testataan PohjoisKymenlaakson alueella. Tulokset osoittavat, että yhden luukun palvelut eli monien toimintojen yhdistäminen saman katon alle ja mobiilipalvelut ovat kustannustehokkaita ja joustavia palveluntuotantomalleja maaseuduille. Tulosten perusteella lisääntyvä monipaikkaisuus tulisi tehdä yhteiskunnassa näkyvämmäksi ja sitä tulisi hyödyntää nykyistä enemmän maaseudun kehittämisen resurssina.
\end{abstract}

Avainsanat: monipaikkaisuus, terveyspalvelut, spatiaalinen optimointi, Pohjois-Kymenlaakson alue, Suomi

\title{
1. Introduction
}

In the simplest definition, multi-local living means that a person or family have more than one residence or place to stay. In Finland, the concept of multi-locality has become common as a phenomenon during the last few decades (Adamiak et al. 2016), but no attention has yet been directed in decision-making or in planning to the effects of multi-local living and working. This is due to the fact that the "invisible population" that arises from multi-locality is not seen in the traditional demographic statistics, which show the individuals as tied to one regular apartment and to one place of residence (Dittrich-Wesbuer et al. 2015). Because of the missing basic information on multi-locality, the planning and service structures of the society and different administrative systems do not sufficiently account for the increasing mobility of people caused by multi-locality. Finnish society is still based on the "single-locality" which is seen in the fact that the regional and social structure and services are planned and developed from the starting points of the permanent settlement structure.

However, multi-locality is common among Finns. For example, in a survey by the Finnish Innovation Fund, Sitra, in their Maamerkit programme in 2011, 38\% of respondents regarded themselves as both urban and rural at the same time (Haukkala 2011). The rural area is linked especially closely to multi-locality through the rural identity, telecommuting, summer cottages and the leisure activities which take place in the rural area. In the near future, multi-locality is predicted to increase further. This is supported by studies in which it is predicted that living in well-equipped 
summer houses as well as multi-locality of living and working in general will increase in the future (Rissanen et al. 2013, 21; Heinonen \& Ruotsalainen 2011). These growing trends are connected with the growth in people's mobility. In spite of this increase, the present position of multi-locality in social planning can be described as marginal, even though, for example, multi-local living related to leisure time increases the vitality and liveliness of rural areas (Pitkänen et al. 2017; Sireni et al. 2017). The citizens' formal rights and obligations are mainly bound to one regular place of residence, in other words to the place of domicile, which at the same time is the starting point for the statistics which serve regional planning.

The biggest multi-local and statistically invisible population group are residents of summer cottages, a seasonal population in the rural area. The number of summer residents has multiplied within a few decades (Adamiak et al. 2016) and it has been estimated that about 2.2 million of the total of 5.5 million Finns regularly spend their time in rural areas (Mökkibarometri = Summer Cottage Barometer 2016). According to Mökkibarometri (2016), the annual average time spent in summer residences is 79 days. This time has lengthened due to the fact that working people commute from the summer house for, on average, 27 days annually. Also telecommuting contributes to multi-locality and for approximately every tenth summer house (60,000 cottages), 12 working days on average were recorded (TEM 2013; Suomen virallinen tilasto (SVT) 2015; Mökkibarometri 2016).

The increase in multi-local living supposedly changes the regional demand for health services and may thus produce unforeseen possibilities to secure health services in the surrounding rural localities and in the bigger municipality centres. Opportunities for planning health services which are related to the statistically invisible multi-local populations are analysed in this article. The objective is to respond to the needs of a changing society and rural areas and to study possibilities for developing health services in rural areas in their entirety to also take into account multi-local residents. The essential question is to better respond to the local needs for services from the permanent population on the one hand, and to intensify the use of these health services by offering them for the use of the seasonal population, on the other.

The assumption of the article is that both the permanent inhabitants as well as summer cottage residents could benefit from multi-locality, and presumably this would also create opportunities to improve the accessibility of health services in rural areas. In this article, multi-locality is understood as multi-local living for leisure time because, of the different forms of multi-locality, it is by far the biggest form in the rural area. At the moment, the planning of health services is based on the permanent registered population, which does not respond to geographical changes in mobility and the changing needs for services especially during the summer time. Multi-local individuals would like to use services on the basis of studies from more than one municipality. According to the Mökkibarometri (2016), for example, the majority (62\%) of summer residents support official dual residency in municipalities. This assumption is tested in the North Kymenlaakso region, Finland, by studying how the demand for health services varies between January and July, and how these seasonal demand changes affect the possible provision of health services and optimization of the health service network in the area. Both questions are connected with the question of how multi-locality could be utilized to improve health services in rural areas.

\section{The research on multi-locality}

\subsection{Development of multi-locality in Finland}

Multi-locality has been internationally studied during the last few decades especially in the research fields of migration and mobility, living and leisure, developing countries, social sciences and family studies (Wood et al. 2015). Dick and Duchêne-Lacroix (2016) compared multi-local living arrangements in the Global South and North. They concluded that multi-local "residential systems" exist in all parts of the world and some of them are very old. The contextual combinations of drivers lead individuals and households to live in more than one residence and to cope with intermittent presence and absence in their living places. These drivers are the result of an intermeshing of structural "necessity", action capacity and living strategy. Multi-local living 
needs at least one anchorage motivation (work, family, etc.) per location (Dick and DuchêneLacroix 2014, 7-8).

The consideration of the development of multi-local living arrangements in contemporary societies raises conceptual as well as methodological questions, and demands new and revised methods for investigating the phenomenon (Schier et al. 2015a). The concept of multi-local living has been used and developed especially by Central-European researchers who have been interested in the spatial manifestations of multi-local living and the everyday practices of a working day, the use of time and mobility as part of multi-local living (Schier et al. 2015b).

Farstad (2013) examined in Norway how second home owners' presence can be perceived as a valuable compensation for a reduced full-time population by the remaining local residents, when it comes to the latter's social needs. The findings indicate that second home owners' presence was highly appreciated as a social compensation for a reduced full-time population, as long as local contextual circumstances did not invite a comparison with new permanent residents as a possible alternative. Müller (2002) states that second home tourism can be considered a good option for contributing to sustainable development in peripheral rural areas of Sweden, e.g., due to its important contribution to local service suppliers. In Estonia, Silm and Ahas (2010) noticed that approximately $5 \%$ of the population of Estonia change their place of residence seasonally. The number of residents rises during the summer months in coastal areas, the surroundings of cities, and in specific 'dacha' areas.

In Finland, multi-locality has been studied mostly from the point of view of multi-local living for leisure time, but the studies have concentrated on describing the phenomenon and determining its scale. Multi-locality has been addressed, for example, from the point of view of multi-local and mobile work (Hyrkkänen \& Vartiainen 2007) and leisure (Pitkänen 2013). The phenomenon has not been connected with the planning or development of services (Adamiak et al. 2016). Thus, multi-locality has not yet been studied at the level of the whole phenomenon (Haukkala 2011).

The position of multi-locality in the margins of society is surprising because there are about half a million summer cottages in Finland and because more leisure homes than permanent ones are located on the majority of our land area (Adamiak et al. 2015). Therefore, there are more and more people living a significant part of the year in a rural area in addition to living in cities, but their official health services are bound to the cities that can be located very far from the summer cottage.

Table 1 illustrates this statistically invisible leisure living connected to counter-urbanization as population changes in the municipality types in 1990-2014. According to the figures, it seems that rural areas are not emptying, because in rural municipalities, the size of the seasonal population has increased by 11.9 per cent, which means about 165,000 new residents as part-time inhabitants (Table 1). The growth in the seasonal population means that the new forms of people' $s$ mobility are a modernizing trend and filling outlying rural areas with new functions and significances. It has been proposed that the rural areas of Finland are developing towards "dropin" or residential rural areas, to where a remarkable part-time or temporary migration is directed related to production and consumption (Rannikko 2008; Pitkänen et al. 2017). This mobility is not seen in the traditional demographic statistics, in which the permanent population of rural municipalities diminished by 12.6 per cent, while population growth is concentrated in urban municipalities (Table 1). 
Tab 1. Population changes by statistical municipality types in 1990-2014. Source: Statistics Finland 2017 and own calculations

\begin{tabular}{|l|c|c|c|c|}
\hline \multirow{2}{*}{ Municipality type } & \multicolumn{3}{|l|}{ Population change in 1990-2014 } \\
\cline { 2 - 5 } & \multicolumn{2}{|l|}{$\begin{array}{l}\text { Statistical (permanent) } \\
\text { population }\end{array}$} & \multicolumn{2}{l|}{ Seasonal population } \\
\cline { 2 - 5 } & Sum (inh.) & $\begin{array}{c}\text { Average } \\
\text { change } \\
(\%)\end{array}$ & Sum (inh.) & $\begin{array}{c}\text { Average } \\
\text { change (\%) }\end{array}$ \\
\hline Urban municipalities & 594,556 & 13.2 & 258,475 & 6.6 \\
\hline $\begin{array}{l}\text { Densely populated } \\
\text { municipalities }\end{array}$ & 8,611 & 2.2 & 74,087 & 6.4 \\
\hline Rural municipalities & $-128,086$ & -12.6 & 164,915 & 11.9 \\
\hline
\end{tabular}

The growth in the seasonal population is regional, especially affecting Järvi-Suomi (Lake District of Finland) area and the eastern and northern parts of the country (Figure 1). In these areas, the seasonal population in several municipalities grew by more than 5,000 inhabitants during the years 1990-2014. This statistical development deviates remarkably from the official registered population development of municipalities, which is generally used as the basis of social planning and decision-making (Lehtonen 2015). The significance of this development is emphasized by the fact that the rural municipalities where the seasonal population has grown are small: on average, their population is 3,961 inhabitants. The seasonal population is a significant part of the vitality of these municipalities because its size is 2.5 times bigger on average than the number of people who are permanently registered to rural municipalities. The growth in the seasonal population has been very general in the rural municipalities, as in as many as 73 per cent of rural municipalities the seasonal population has grown during the years 1990-2014 (Figure 1).

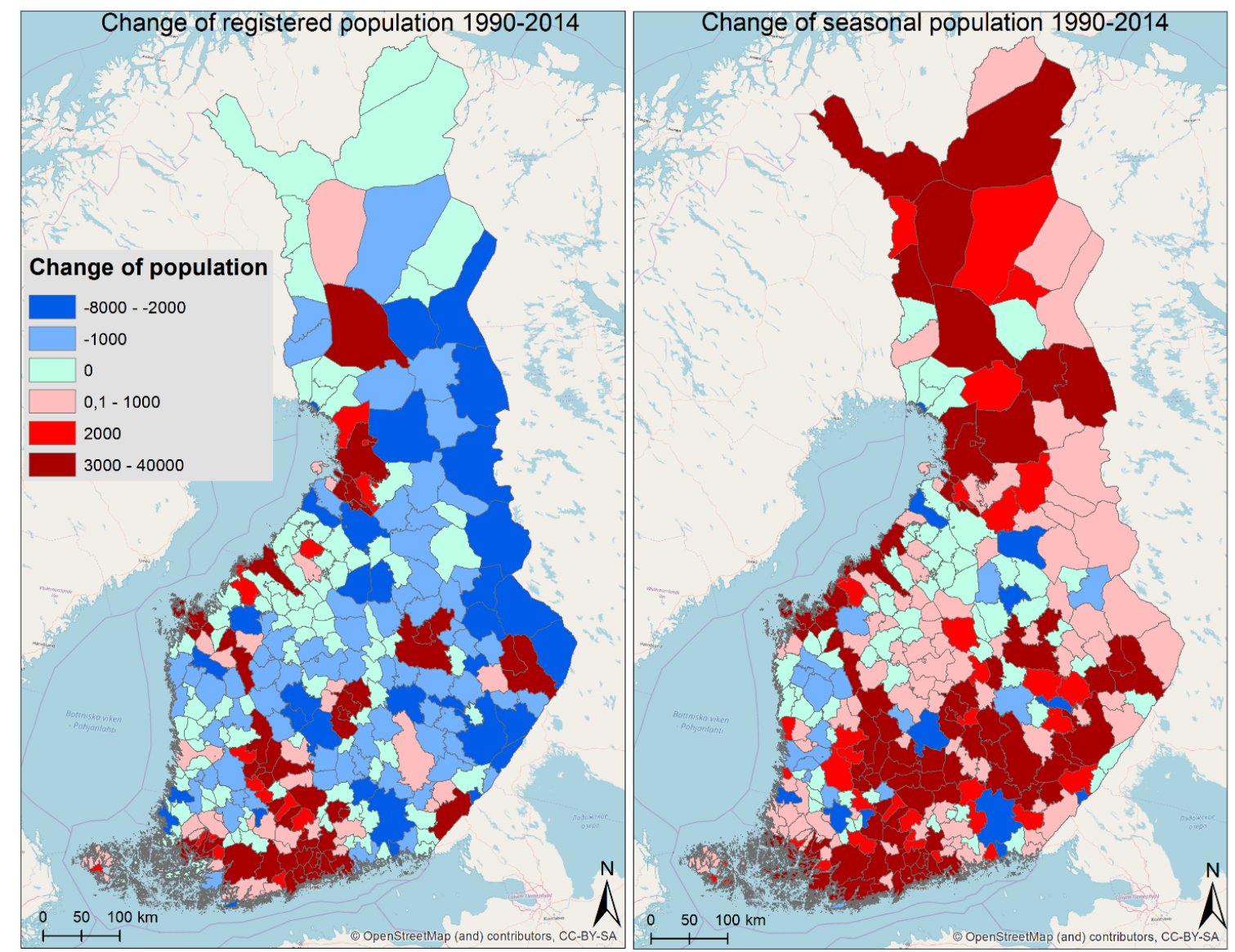

Fig 1. Development of the registered and seasonal population by municipalities in Finland in 1990-2014. Source: Suomen virallinen tilasto (SVT) 2013; Statistics Finland 2017 and own calculations 
The strong growth in summer house settlement emphasizes the significance of the part-time seasonal population as users of services in municipalities. The purchases of the seasonal population improve the operational preconditions of the companies which operate in the municipalities and thus indirectly increase the incomes of the municipalities (Saaristoasiain neuvottelukunta 2006). According to a survey report which examines the summer residents' use of services, they use mostly cultural services, building inspection services, the duty reception of the health centre and the library in the municipality of their summer residence, although domiciled officially outside the municipality. Cultural events, museums and other cultural services were used by $40 \%$ of the summer residents on the basis of the survey, physical education services $12 \%$, library services $17 \%$ and health services $25 \%$ (Saaristoasiain neuvottelukunta 2006). The use of health services by summer residents is reduced by the fact that in non-urgent cases, the patient is directed to the health services of his or her municipality of official domicile. This is due to the fact that under the Public Health Act health care, expenses are charged to the patient's domicile to where they are directed for treatment. This is the case even if it would be in the best interests of the patient to provide care at the nearest health centre even in non-urgent cases (Saaristoasiain neuvottelukunta 2006).

\subsection{Towards new service provision models adapted to the changes in demand}

Multi-locality provides new opportunities for creating or maintaining health services in rural areas if attention is paid to the summer residents and to other seasonal inhabitants as a potential and additional customer group for the services. The health services in rural areas of Finland have suffered from centralization and a loss of accessibility during the past few years when health services were moved further away from inhabitants to the largest centres (Leinamo 2010, 118 - 120; YTR 2009, 49; Rehunen et al. 2012). This change challenges the providers of health services to develop new and better tailored service provision models which provide new opportunities to improve the availability of health services within the rural area.

Digital health services which can improve the availability of services, intensify the evaluation of the need for care, diversify the service selection, reduce the loneliness of elderly people and save costs, are considered as one alternative to the health services of the rural area (Antikainen et al. 2016; Ministry of Social Affairs and Health 2017; Moussa et al. 2017.) In spite of clear advantages, the use of digital health services is still quite limited and is restricted mainly to on-line appointments that complement traditional forms of services (Antikainen et al. 2016). In rural areas, the use of digital services is reduced by the elderly age structure and the lack of efficient Internet connections (Pyykönen \& Lehtonen 2016). In North Kymenlaakso region, few digital health services are used and they are emphasized merely for appointments in the occupational health service, dental care and child welfare clinic services or for the completing of patient information electronically. Thus, the digital health services are not yet an alternative to the large-scale provision of services in rural areas (Lehtonen 2017).

Another alternative to health services in rural areas are one-stop centres where several different services are provided in a single building. The possibilities of arranging multi service centres are good because the service network of the rural area in Finland is still relatively well covered. In most centres of more than 1,000 inhabitants, there is a grocery shop, elementary school and health centre, which are natural sites for one-stop centres. According to Moseley and Owen (2008, 109), declining local demand has resulted in multi service centres becoming common especially in the UK. Also in Finland, there have been experiments with different multi service centres but they have been located mainly in urban areas and municipality centres (Tuorila 2002, 61). Experiments have also concentrated mainly on bringing together commercial services, e.g., to bring postal services to grocery shops.

The cost efficiency of the one-stop centre is based on the fact that property overheads can be distributed between different service providers (Moseley \& Owen 2008). In practice, cost savings will be achieved by utilizing unused or underutilized resources, such as spare rooms. In the health services, this means, for instance, using the premises of the public health nurse of the school when the nurse is not working in the school and when the facilities are available. As an advantage of the multi service centre, Moseley et al. (2004) also state that service users often accept the centre as being better than no service provision at all in the area. The one-stop centre is 
an attractive option especially when local services are scarce. In this case, the alternative will be either a long trip to the nearest service centre or mobile services if they are available. The drawbacks of the one-stop centre are connected to both. Also, with their own limitations, multi service centres can offer notable advantages, especially to car-free older people and to disabled consumers. It is also possible to offer services in one-stop centres that it would not be costefficient to provide in separate locations in sparsely inhabited areas. The most significant disadvantage of multi service centres is their complexity regarding administrative matters and management (Moseley et al. 2004).

As a third option, alongside population development and the concentration of health services, more and more mobile health services have been brought into use in municipalities during the last few years (Lehtonen 2017). The advantage of mobile health services, as stated in the reports, is that they improve the availability of health services by offering high-quality primary health care services cost-effectively in locations where service points are scarce. So, mobile health services supplement the already existing service selection of fixed health centres. Mobile services also offer means to secure health services in those rural areas where they are concentrated without significantly weakening the experienced availability of services. In particular, mobile health services are seen in rural areas as a solution to providing the primary health care services which are often needed. Thus, the mobile health service does not need to be its own separate form of activity (Immonen et al. 2012). They are not a solution which serves only sparsely populated areas either, because a mobile health care car can similarly circulate in the suburbs of cities. One example of mobile health services is the "Mallu" car operating within the social and health circle (Eksote) of the South Karelia region. It offers the services of nursing, dental care and service guidance in South Karelia. The Mallu car is a mobile nursing reception which provides also oral health care preventive services and laboratory services for INR sampling (Immonen et al. 2012). Mobile services are not without problems because they require effective communication to all potential users on available days, times and places because these vary from day to day (Wikström-Koikkalainen et al. 2014).

\section{Data and methods}

The possibilities for the provision of health services related to multi-local living are examined in this study in North Kymenlaakso, Finland, which consists of the city of Kouvola and the municipality of litti. Together, the municipalities form a sub-region of about 92,000 inhabitants. In 2016, there were 8 health centres in the area, located in the more densely populated urban areas (Figure 2). In the same year, there were 38 schools in the region, which were also concentrated in the more densely populated urban areas (Figure 2). In 2016, there were 10,516 summer cottages in the research area, whereby the promotion of multipurpose housing and a comfortable living environment is one of the focus areas for the growth strategy of the study region in 2014-2020. The large number of summer cottages means that there is a high potential demand for local services especially during the summer time. Summer cottages are particularly concentrated in the northern part of the area, where the largest lakes in the region are located (Figure 2).

The assessment of the significance of multiple residence for the provision of health services is based on the calculation of economic incentives where the maintenance and mobility costs of the health service network are compared with 4 service production models (Table 2). The first 2 models are based on the existing health centre network and its optimal extension. The third model is based on multi-services where primary school premises are utilized in the provision of health services, and the fourth model is based on mobile health services. 

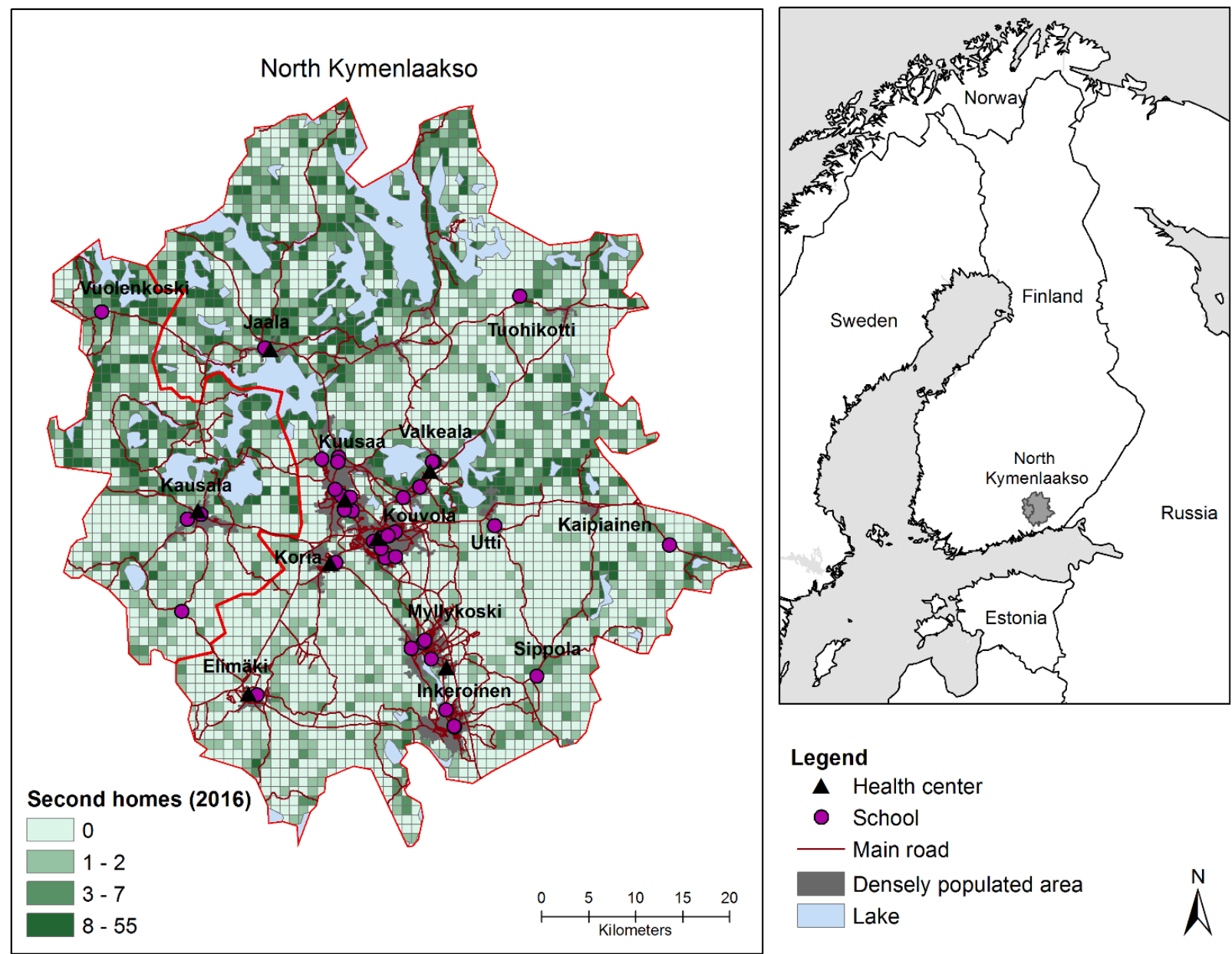

Fig 2. Quartile map of the number of summer cottages (second homes) in the study area. Source: Statistics Finland 2017; Suomen virallinen tilasto 2017 and own calculations

The calculation focuses on the geographical characteristics and relationship between the maintenance costs of the health service facilities and the travel costs. When the size of the health service network increases and accessibility improves until the savings in travel costs are greater than the increase in maintenance costs in the area of the new health service, one can suppose that there are economic incentives to establish the new health service and for the decentralization of the health service network. This is due to the fact that in this case, seeking health services will be less expensive than the maintenance costs of the opening of the new health service.

The weakness of the calculation in the study is that it does not consider the differences in labour costs and the possible differences between them in the health centres. Also, the lack of statistical data on multiple residence and the use of multi-site human health services weakens the reliability of the calculation. The calculation is a rough estimate, however, for the first time, it considers multiple residence as part of the planning of health services. 
Tab 2. Provision models of the health services that have been used in the cost accounting.

\begin{tabular}{|l|l|l|l|}
\hline $\begin{array}{l}\text { Provision } \\
\text { model }\end{array}$ & $\begin{array}{l}\text { Channel of the } \\
\text { health service } \\
\text { provision }\end{array}$ & Explanation & $\begin{array}{l}\text { Source of } \\
\text { information }\end{array}$ \\
\hline $\begin{array}{l}\text { Expanded } \\
\text { network of health } \\
\text { centres }\end{array}$ & $\begin{array}{l}\text { Journey to access } \\
\text { service (fixed facility) }\end{array}$ & $\begin{array}{l}\text { In the cost calculation, it is assumed that } \\
\text { the costs of establishing the health } \\
\text { centres follow the costs of existing health } \\
\text { centres so that they will correspond to the } \\
\text { demand for the service. }\end{array}$ & $\begin{array}{l}\text { Municipalities } \\
\text { of the region }\end{array}$ \\
\hline $\begin{array}{l}\text { Optimized } \\
\text { network of health } \\
\text { centres }\end{array}$ & $\begin{array}{l}\text { Journey to access } \\
\text { service (fixed facility) }\end{array}$ & $\begin{array}{l}\text { In the cost calculation, it is assumed that } \\
\text { the health centres network adapts itself to } \\
\text { the demand in which case there is no } \\
\text { extra capacity. The only extra costs are } \\
\text { created by the opening of new health } \\
\text { centres. }\end{array}$ & $\begin{array}{l}\text { Municipalities } \\
\text { of the region }\end{array}$ \\
\hline $\begin{array}{l}\text { Health services } \\
\text { as multi-services }\end{array}$ & $\begin{array}{l}\text { Journey to access } \\
\text { service (fixed facility) }\end{array}$ & $\begin{array}{l}\text { In the cost calculation, it is assumed that } \\
\text { the health services can be provided in } \\
\text { local schools. The health service } \\
\text { providers pay to the school system a } \\
\text { monthly rent which is 10 per cent of the } \\
\text { annual maintenance costs of the schools. }\end{array}$ & $\begin{array}{l}\text { Municipalities } \\
\text { of the region }\end{array}$ \\
\hline $\begin{array}{l}\text { Mobile health } \\
\text { services }\end{array}$ & $\begin{array}{l}\text { Service that is brought } \\
\text { to the region/customer } \\
\text { (mobile facility) }\end{array}$ & $\begin{array}{l}\text { The information about the cost accounting } \\
\text { is based on the Mallu service car } \\
\text { (Heiskanen \& Värtö 2011). Location of } \\
\text { health services (10 in total) is based on } \\
\text { spatial optimization where the stops can } \\
\text { be located freely in the area of North } \\
\text { Kymenlaakso. }\end{array}$ & $\begin{array}{l}\text { Eksote, Mallu } \\
\text { service car }\end{array}$ \\
\hline
\end{tabular}

\subsection{Registered and average populations}

Population statistics at sub-national level are usually gathered for administrative units (e.g., LAU $=$ Local Administrative Units, municipalities). An alternative approach is to divide the territory into a regular grid of small rectangles of the same size. Population figures and other data are assigned to certain rectangles (grid cells) based on the exact georeferenced locations of places of residence, properties or companies. Statistical grid databases are increasingly used in population studies in the Nordic countries (Amcoff 2006; Kotavaara et al. 2011; Kotavaara et al. 2015). Performing spatial population analysis independently of administrative boundaries helps to avoid several methodological pitfalls, such as the effect of "urban spillover" (Amcoff 2006) or large administrative units covering disparate areas: in Finland, especially in the northern part of the country, municipalities cover large areas which may be predominantly uninhabited but contain municipal towns where the local population is concentrated (Muilu \& Rusanen 2003).

In our analysis, we use the YKR database (Monitoring System of Spatial Structure and Urban Form), one of the most advanced georeferenced statistical databases in the world enabling to perform nationwide analyses using GIS (Geographic Information System) methods. The YKR database is created and maintained by the Finnish Environment Institute, and it comprises data on population, housing, workplaces and travel to work from the year 2016 for each of about 6.3 million $250 \mathrm{~m} \times 250 \mathrm{~m}$ square-shaped grid cells into which the territory of Finland is divided. We generalized the original data into a lower spatial resolution of $1 \mathrm{~km} \times 1 \mathrm{~km}$ cell size, as this resolution is sufficient for the purposes of the study and generalization facilitated computing and graphical presentation of the results.

In order to take into account the role of summer cottage use in the population distribution, we analyse not only the registered population numbers $(R P)$, but we also calculate the average population $(A P)$, which, in turn, measures the average number of people present in the area throughout July (see Adamiak et. al 2016). We assume that the registered population describes the population numbers for January because it shows the size of the population on the last day of December. The use of the average population for planning health services can be justified by 
the fact that it does not underestimate the potential demand for health services as it recognizes the movement of people.

The average population $(A P)$ describes the population after taking into account the annual use patterns of primary homes and summer cottages. For July 2016, it was calculated as

$A P 2016_{i}=R P 2016_{i}+\operatorname{sh} 2016_{i} *$ users $2010 * \frac{\text { days }}{31}-R P 2016_{i} * \operatorname{access}_{2010} * \frac{\text { days }}{31}$

where the variable AP2016, represents the average population of a given grid cell $i$ in the July 2016. $R P 2016_{i}$ describes the registered population in a similar way. The variable sh2016istands for the number of summer cottages in cell $i$ in 2016. For 2016, we used the real number of summer cottages according to the YKR data. The constant users denotes the average number of people using one summer cottage, which is 4.2, according to the LVVI study (2010). The variable access 2010 denotes the shares of grid cell population that had access to a summer cottage in 2010 and based on the LVVI study (2010), it was set to 0.40 . The constant days describes the national average of the number of days spent in summer cottages by their users in July which was according to a recent study 16.7 days in July (Mökkibarometri 2016). The variables users and access are based on the year 2010 because there are no more recent studies on these themes. The last Longitudinal National Outdoor Recreation Survey (LVVI 2010) was conducted in the years 2009-2010 and targeted to a random sample of almost 9,000 Finns.

The potential demand for health services in January and July is estimated based on the average local use of health services in 2016. In the study area, the average annual use of health services was 2 visits. For January and July, the potential demand (S) was calculated by multiplying the registered and average populations with average monthly visits as
$S_{\text {January }, i}=R 2016_{i}^{*} A$
(2) and
$S_{J u l y, i}=A P 2016{ }^{*} A$

The average monthly visits (A) per person in 2016 was 0.17 (Hilmo 2017).

\subsection{Maintenance costs for health service networks}

Detailed location information for the establishment of a health service network from existing health centres and their annual maintenance costs was obtained from the municipality of litti and the city of Kouvola. In addition to the health centres, the study included 38 primary school facilities, assuming that multi-service health services could be organized in some of these buildings located in the study region. In the health service network optimization (section 3.3.1), only the optimal locations of the primary schools were selected for study. The maintenance costs were estimated from the total maintenance costs of the primary schools whereby a monthly rent would be 10 per cent of the annual total maintenance costs of the school property on an expert interview.

The maintenance costs of the health centres and multi-services were estimated with a linear regression model where maintenance costs $\left(C_{\text {maintenance, }}\right)$ are explained by the demand $\left(D_{j}\right)$ directed to service points $\mathrm{j}, \mathrm{j}=9 . .20$. A regression model was defined as follows:

$$
C_{\text {maintenance, } j}=\alpha+\beta D_{i}+\varepsilon
$$

The potential demand for the health services were defined by calculating the service areas for current health centres and multi-services by assuming that the demand for health services will be directed to the closest service point. The estimation of the regression models generated the following regression models for new health centres $\left(\mathrm{C}_{\text {center }}\right)$ and multi-service points $\left(\mathrm{C}_{\text {multi }}\right)$ :

$$
\begin{array}{ll}
C_{\text {center }, j}=26910+36,9 * x_{i} & \left(\mathrm{r}^{2}=0,783, \text { F-test } 26,36, \mathrm{p} \text {-value } 0,002\right) \\
C_{\text {multi }, j}=14408+5,8 * x_{i} & \left(\mathrm{r}^{2}=0,639, \text { F-test } 20,54, \mathrm{p} \text {-value } 0,001\right)
\end{array}
$$


In the regression models, it is expected that the maintenance costs of the health services are linearly connected with the demand for health services. The regression coefficients show that the maintenance costs of the health centres are about 2 times bigger than the fixed maintenance costs revealed by the fix terms of the multi-services. The regression coefficients show that the maintenance costs in response to the demand are 6 times higher for health centres than for multi-services.

\subsection{Health service network}

A flowchart of the implementation of spatial data analysis of the health service network is summarized in Figure 3. In steps 1 and 2, the health service network is optimized and the accessibility to health services is measured by means of road distance. The travel costs are estimated in step 3. In the final step, relationships between maintenance and travel costs are analysed. The steps of the analyses are described in more detail in the following chapters.

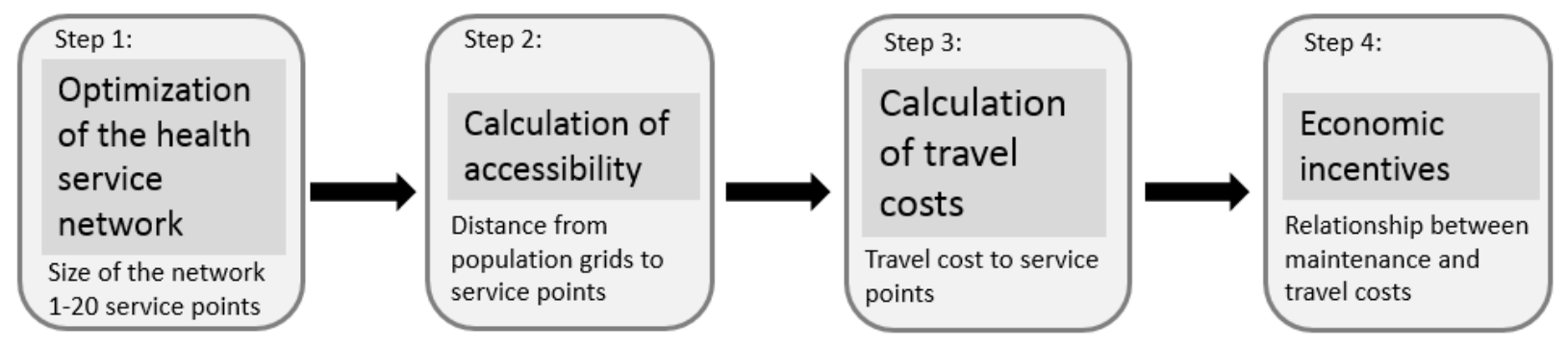

Fig 3. Flowchart of the methods used in the study.

\subsubsection{Spatial optimization of the health service network (step 1)}

The opportunities for multiple residence in the production of health services will be studied in a spatially optimized health service network. Optimization of location of health services is done by using the Network Analyst tool from the ArcGIS software. Optimization is done as a road-based optimization with the minimize impedance method. Hakimi (1964) defines the idea of this method as follows: the aim is to find a median point in a service network so that the distance or time between each point used is minimized. The method is commonly used in optimizing problems with the aim of reducing impedance, for instance, costs which can be the time or physical distance between the demand point and the service. This method has previously been used to optimize the hospital network in Finland (Huotari et al., 2012; Huotari et al., 2013).

In the spatial optimization conducted in this article, the health services may possibly be locating either in existing health centres or in schools located in the study area. The health service stops for mobile services were freely available anywhere in any research area. For the latter option, a $100 \mathrm{~m} \times 100 \mathrm{~m}$ grid was created in the area, with centroids of possible locations for health service stops. In the optimization, the population grids were weighted by their population. The size of the health service network ranged from 1 to 20 service points in the optimization, and whenever the size of the network increased, an optimal health service point was added to the network.

\subsubsection{Accessibility of the closest health service point (step 2)}

Accessibility is generally described by distance, time or travel costs (Kwan 1998). In this study, the accessibility of health services in an optimized health service network is simply estimated by the shortest distance to the nearest health service point. The use of the shortest distance is related directly to the parameters used in the calculation of travel costs which were given related to the distance (see Section 3.3.3). Thus, this assumption of the shortest distance minimizes the travel costs in the calculation.

Accessibility of the health services has been calculated using the Network Analyst tool from ArcGIS software. Accessibility calculations from the population grids to the nearest health service point were made using the closest facility method based on Dijkstra's algorithm (Knuth 1977). The method finds the shortest distance or time-based route from the centroid of the population 
grid to the health service point. The accessibility data used in the calculation is based on the Digiroad road network from the year 2016 (Digiroad 2016). In the accessibility calculations, it was assumed that the health services would be used from the residence (January) or from the summer cottage (July).

\subsubsection{Calculation of the travel cost to the closest health service point (step 3)}

Travel costs to health services comprise fixed costs and changing operating costs which are related to the location and accessibility of services, transport infrastructure, administrative constraints, energy costs and means of transportation (Rodriguen et al. 2013). The accessibility of the service is often the most important factor affecting travel costs as it determines travel time and costs related to it (Rodriguen et al. 2013). This study focuses only on distance-related costs because costs that are related to travel time are difficult to generalize. Based on the calculation of accessibility, the health service costs $\left(\mathrm{C}_{\text {health }}\right)$ were calculated as follows:

$C_{\text {Health }}=C_{\text {travel }}+C_{\text {treatment }}$

where $C_{\text {travel }}$ is the annual travel costs and $C_{\text {treatment }}$ is the annual treatment costs. Since health service customer fees do not differ between municipalities in the region, the differences in the health service costs for the users are determined only by the travel costs that depend on the accessibility of the health services. Thus, the health service costs in population grid $i\left(\mathrm{C}_{\text {health,i }}\right)$ are calculated by multiplying monthly travel costs $\left(\mathrm{C}_{\text {trave }}, \mathrm{i}\right)$ with the average monthly visits to the health services $\left(S_{J a n u a r y, i}, S_{J u l y, i}\right)$.

$$
C_{\text {Health }, i}=C_{\text {travel, } i} * S_{i}
$$

To simplify the calculation, a private car and a taxi with a Kela compensation were chosen as the travelling options to the health services. This is an especially useful simplification in rural areas because they often lack comprehensive public transport (Helminen et al. 2003), and therefore, the use of private car or taxi is mandatory. In the summer time, the public transport in rural areas is also less frequent because schools and the public transport that supports them are not in operation. In addition, there were a great number of areas in the study region that did not have any public transport services partly because the planning of the bus routes is based on the statistical population. In general, the car is also a very common form of mobility since, according to a passenger traffic survey, 58 percent of all trips in Finland are made by car (Liikennevirasto 2012). The calculation of the travelling costs for health services in the population grid $\mathrm{i}$ is determined by car and taxi without time expense.

The calculation of the travel costs $\left(\mathrm{C}_{\text {travel, }, \mathrm{i}}\right)$ was made as follows:

$$
\begin{aligned}
& C_{\text {travel }, i}^{\text {car }}=D * C_{\text {car }} * S_{i} * 2 \\
& C_{\text {travel }, i}^{\text {KELAcar }}=D * C_{\text {KELAcar }} * S_{i} * 2 \\
& C_{\text {travel }, i}^{\text {taxi }}=\left(\left(D * C_{\text {taxi }} * S_{i}\right)+C_{\text {start }}\right) * 2-25
\end{aligned}
$$

where $S_{i}$ is the total amount of trips for health services of population grid $i, D$ denotes the distance $(\mathrm{km})$ from population grid to the nearest health service point, $\mathrm{C}_{\mathrm{car}}$ denotes the operating costs of private car per kilometre $(€)$ and $\mathrm{C}_{\text {KELAcar }}$ denotes the compensation paid by Kela (the Finnish Benefits Agency) for the use of a private car. Taxi trips are also subject to a minimum charge $\left(\mathrm{C}_{\text {start }}\right)$ and the operating cost of taxi $\left(\mathrm{C}_{\text {taxi }}\right)$ per kilometre. Because the trips are two-way, the equations are finally multiplied by two. Private car operating costs are set at $0.43 € / \mathrm{km}$ 
(Veronmaksajat 2016). The Kela compensation for using a private car is $0.20 € / \mathrm{km}$. The minimum charge for a taxi is $5.90 €$ in Kymenlaakso and the operating cost is $1.50 € / \mathrm{km}$. From the travel costs by taxi, a deduction of $25 €$ is reduced from the costs (Kela 2017).

\subsubsection{Comparison of saving in the travel cost with maintenance costs (step 4)}

Evaluation of the economic incentives for the opening of new health service points in the health service network is related to the relationship between the savings in the travel costs generated by the new health service point and the maintenance costs of the service point. If the savings in the travel costs are high in the service area and exceed the maintenance cost of the health service point, there is a positive economic incentive to open the service point because opening the service point saves users or society's money more than the cost of maintaining the health service point would be. The economic incentive thus calculated is of a theoretical nature, since the travel costs and maintenance costs are allocated to different parties. For the calculation, the saving of the travel costs in health service point $j$ ( $\left.S^{\text {health,j}}\right)$ is defined as follows:

$$
\begin{aligned}
& S_{\text {car }}^{\text {Health }, j}=\sum C_{\text {car }, i}^{\text {Health }, j-1}-\sum C_{\text {car }, i}^{\text {Health }, j} \\
& S_{\text {KELAcar }}^{\text {Health } j}=\sum C_{\text {KELAcar }, i}^{\text {Health }, 1}-\sum C_{\text {KELAcar }, i}^{\text {Health }, j} \\
& S_{\text {taxi }}^{\text {Health }, j}=\sum C_{\text {taxi, } i}^{\text {Health-1 }}-\sum C_{\text {taxi, } i}^{\text {Health }, j}
\end{aligned}
$$

where savings in the travel costs of the health service point $\mathrm{j}$ are calculated by reducing the travel costs of the smaller optimal health service network from the travel costs of the larger health service network. If this saving exceeds the maintenance cost of the health service point $\left(Y_{j}\right)$, then economic incentives can be found to open the health centre or multi-service point. In the calculation, the health service points, $j=1, \ldots, 20$, are opened in the order in which they belong in the optimal health service network when the size of the network is enlarged. When interpreting the results of the calculation, it should be kept in mind that, because of the absence of precise statistical data, the calculation results are only indicative.

\section{Results}

\subsection{Multiple residence changes the geographical demand for health services}

In the research area in North Kymenlaakso, the population will grow larger in July than in January, which will increase the demand for health services in the area. In July, the population in the region is about 3,653 more than in January. The geographical demand for health services also changes, as the January and July populations differ significantly. In July, the population grows particularly in the northern parts of the region, where the population concentrations around the lakes are shown in Figure 4. Statistics on the population and the average population are based on estimates for the demand for available health services in January of 15,391 and in July 16,000 visits.

Due to multiple residence, the geographic demand for health services will change considerably. In July, the change in demand affects in total 22,019 inhabitants in the population growth areas of Figure 4. On an individual population scale, there is an average growth of 15 people, corresponding to a 343 per cent increase in the July population, which is an average of more than 3 -fold in each population. Because of seasonal mobility, in July, the population is mainly reduced in the densely populated areas (Figure 4). Compared with January, the population decrease in July agglomerations has a total of 18,016 inhabitants. On average, the population loss is 22 inhabitants, which accounts for about 21 per cent of the average population in January of these population grids. 


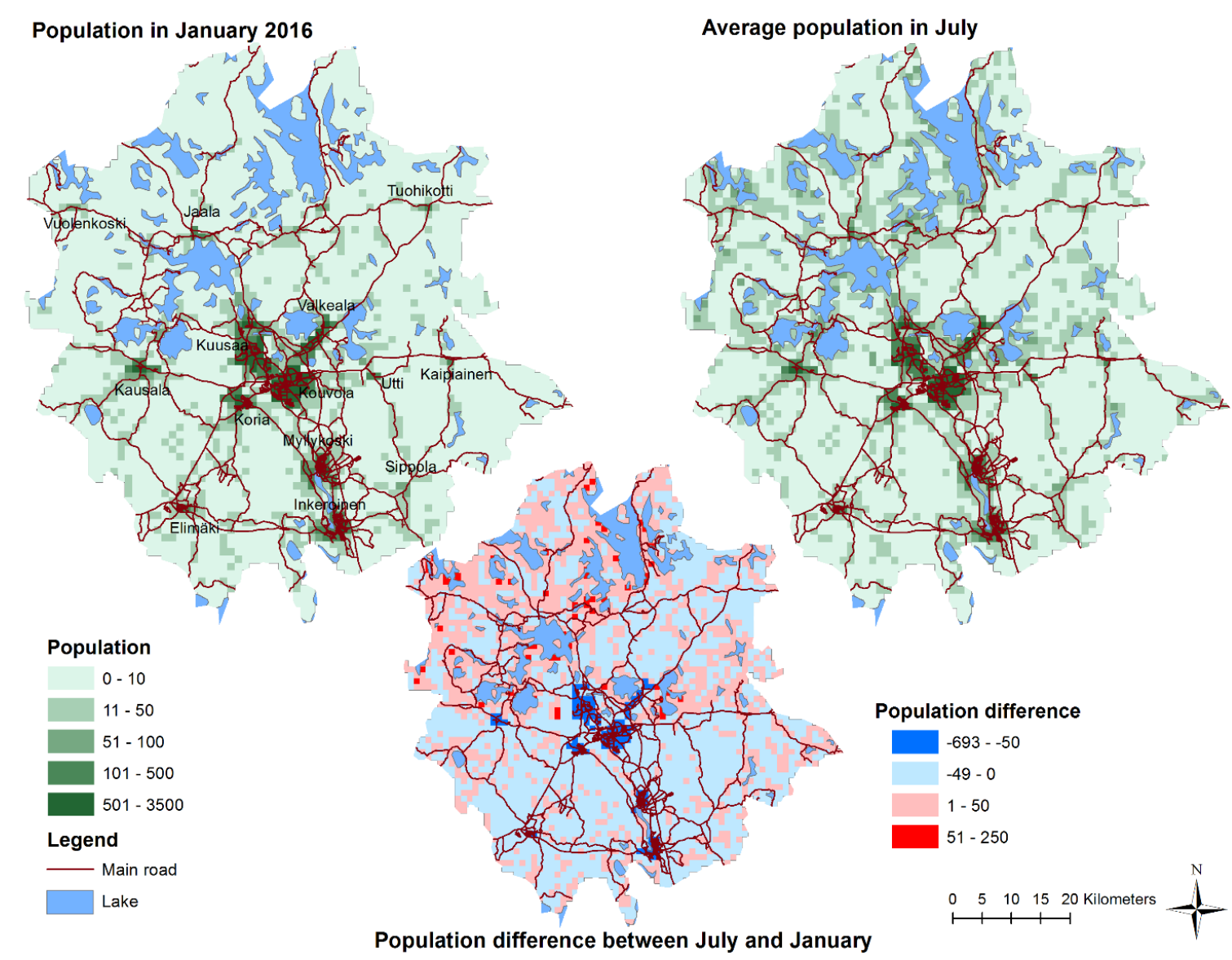

Fig 4. Population in January and July and their difference in the study region.

\subsection{The cost of the optimized health service network in January and July}

The results of the cost accounting show that increasing the number of health centres by increasing the size of the existing health centre network in optimized networks, increases the monthly maintenance costs of the health service network strongly in January and July (Figure 5). The provision of health services in school buildings with multi-service points has a considerably lower cost of maintenance compared with the extension of the health centre network (Figure 5), even though the maintenance costs of the multi-service points increase as relatively stable. The maintenance costs of the health services produced at multi-service points are approximately 34 per cent lower when the size of the health service network is 20 service points than in a health centre network of equivalent size.

The maintenance costs of the health services are the lowest for mobile services (Figure 5). In this option, the maintenance costs are about 26 per cent lower than the equivalent costs for multiservice points and about 51 per cent lower than the equivalent costs for health centres. However, the comparison of the mobile service provision model to the other two provision models is difficult because the maintenance costs of the mobile services are not compared with the demand for health services, unlike in the other two production models. It must also be remembered that the aim of the mobile services has been sought opportunities to complement the traditional health services in distant rural areas.

Travel costs for health services fall strongly in both months to about 8 service points. Subsequently, the decline in the travel costs is more moderate in both months, and the increase in the size of the service network and thus decentralization of health services will not significantly reduce the travel costs (Figure 5). Between January and July, however, there are large differences in the amount of travel costs, due to the geographical changes in the demand for the health services. 
For example, the travel costs for the use of private car are calculated at 80 per cent higher in July than in January with the network of 8 health service points. Travel costs based on taxi fares are even higher because in July, the calculated travel costs are about 5 times higher than in January. This is due to the fact that in July, the number of long journeys increases, which also increases the number of journeys that are bigger than deductible by 25 euro. At the lowest, the travel costs are calculated on the basis of passenger car subsidy paid by Kela which is with a 20 service points network about 34,341 euro in July, while the corresponding travel cost is approximately 17,083 euros in January (Figure 5). Correspondingly, the highest travel costs are found when travel is made by taxi and when the service network consists of only 1 point. Then the costs are approximately 425,642 in July and about 180,711 euro in January (Figure 5).
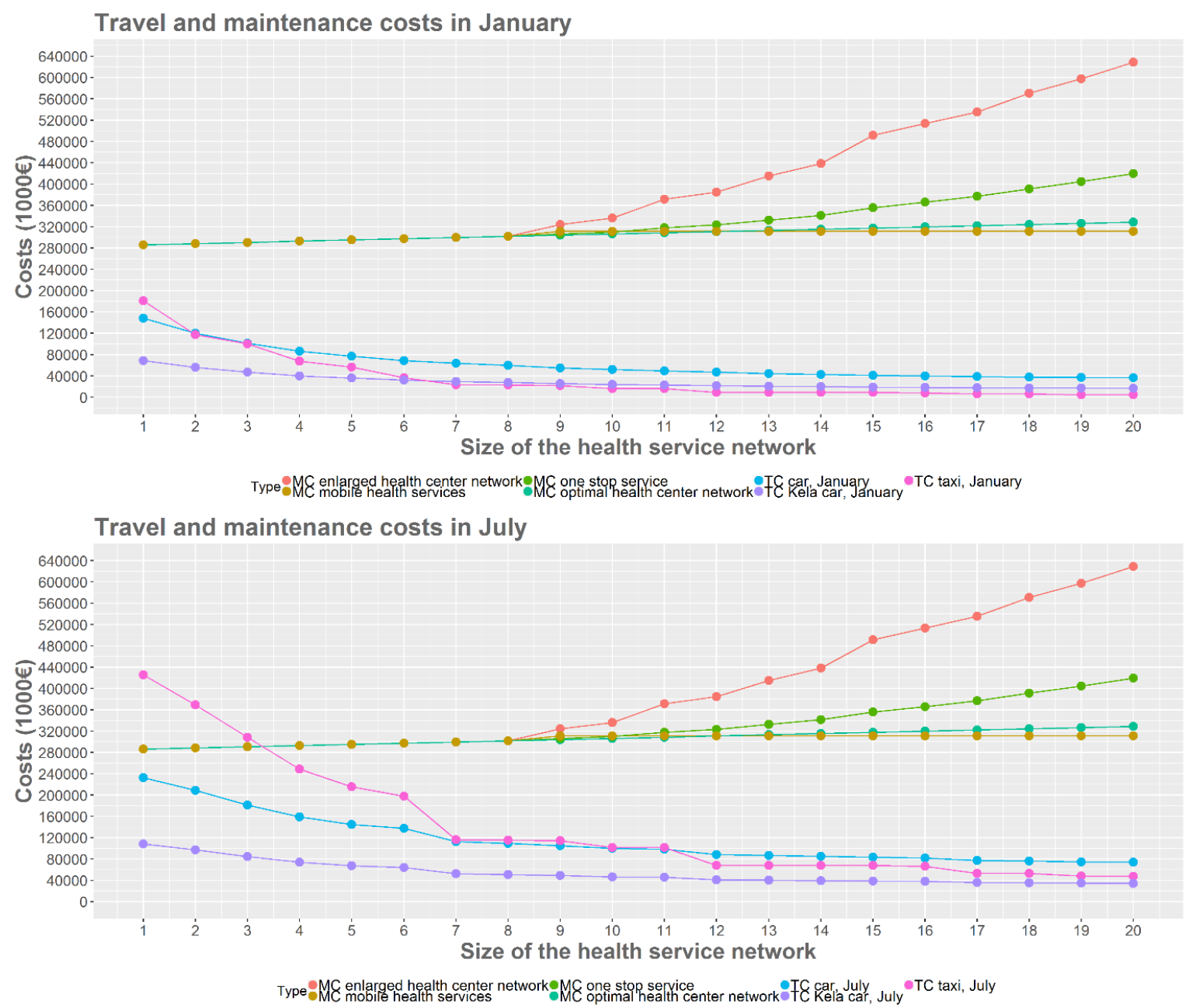

Fig 5. Maintenance and travel costs of different sizes of health service networks.

The comparison of maintenance and travel costs reveals that in general, in January, the travel costs are lower than the maintenance costs (Figure 5). For example, in January, when the health service network is composed of one service point, the difference between maintenance and travel costs is at its lowest, the maintenance costs are approximately 105,510 euro higher than the travel costs. Thus, because the maintenance costs are higher than the travel costs, there appears to be no economic incentive to decentralize health service provision in the study region in January. However, in July, when the geographic demand for health services changes, the ratio of maintenance and travel costs also changes, and the travel costs exceed the maintenance costs (Figure 5). In July, the travel costs based on taxi fares are for up to 3 service points higher than maintenance costs, which encourages the decentralization of service production to at least 4 locations. 


\subsection{Costs by service points in January and July}

The overall cost review of the above in relation to the size of the health service network cannot deduce the economic incentives associated with individual health service points. Therefore, the relationship between maintenance and travel costs is analysed by the service area in Figure 6 , which compares the monthly maintenance costs for health services with the savings generated by the service points in the monthly travel costs per user. Savings in the service area for travel costs are calculated by comparing the costs of travelling to the health service point with the situation in which the nearest health centre does not exist, and health services would be sought from the second closest service point.

The review of Figure 6 shows a big difference in the economic incentives for the decentralization of the health service network in the various months. In January, only 1 new health centre in Tuohikotti could be opened and only when the travel costs are calculated by means of taxi fares (Figure 6). However, the economic incentive to open this service point would not be great because the monthly travel costs exceed the monthly maintenance costs by only 349 euro.

The growing demand for health services in July increases the economic incentives for the expansion and decentralization of the health centre network. In addition, in July, the economic incentives are not dependent on the one method of calculating the travel costs (Figure 6). Economic incentives are found with taxi fares for four health centres and by car for two health centres. There are no economic incentives for the Kela subsidy of the use of the private car. However, the magnitude of the economic incentives generated by these new health service points varies considerably. The biggest savings on travel costs, a total of 39,933 euro a month, are achieved when the calculation is based on taxi fares. The corresponding savings on the travel costs by private car are 4,264 euro per month. Apart from taxi fares, the calculation shows that it is not very cost-effective to extend the current scope of the health service network.

A more cost-effective production model for rural health services is a multi-service model for extending the health service network, where the provision of health services utilizes an existing school network (Figure 6). The greater economic incentives for the multi-service model are because their maintenance costs are considerably lower than the corresponding costs of health centres, as several operators share the maintenance costs of the premises. This is reflected in the calculation, for example, that in January, there would also be economic incentives to open multi-service points in the school network when the calculation of the travel costs is based on private car or taxi fares (Figure 6). In the case of the private car, the monthly savings generated

by multi-service points are, however, small, as they amount to 1,565 euro. The savings generated by taxi fares are slightly higher, around 8,886 euro per month. 
Travel and maintenance costs by service points

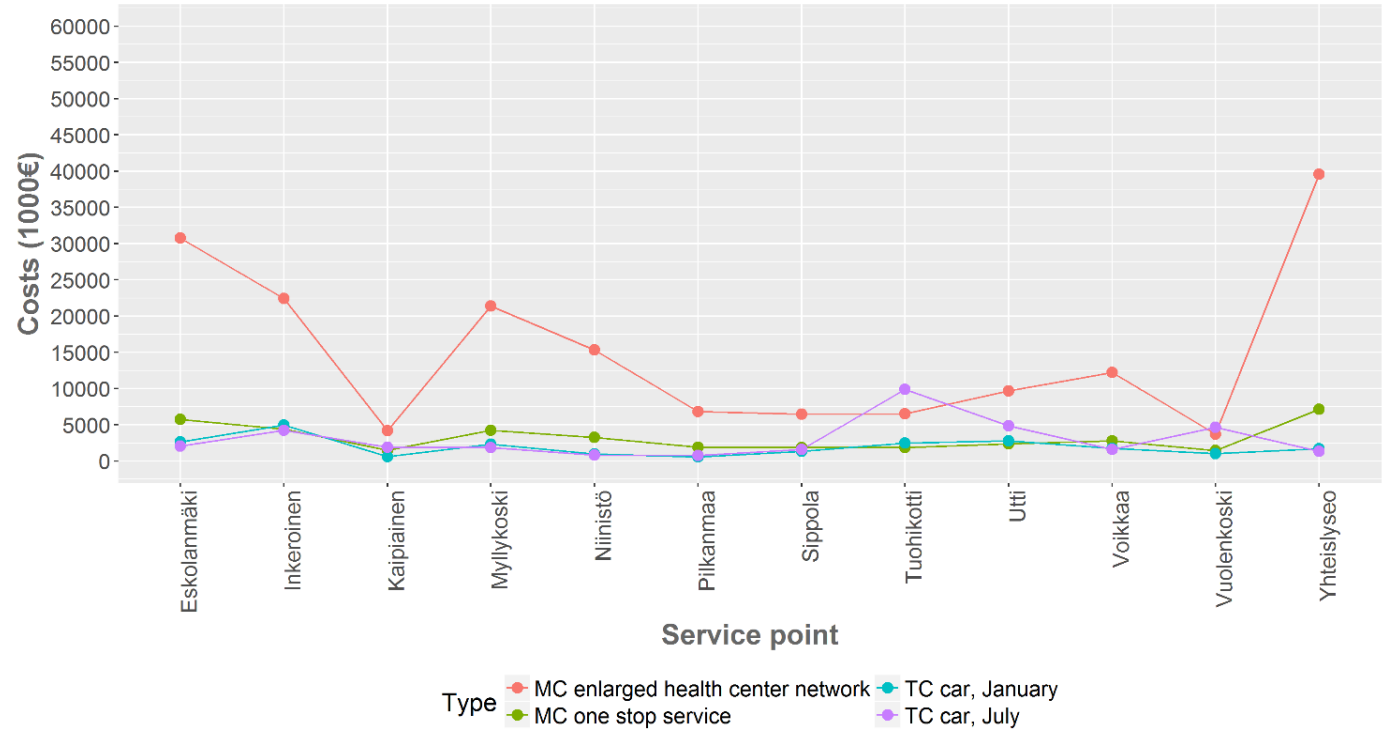

Travel and maintenance costs by service points

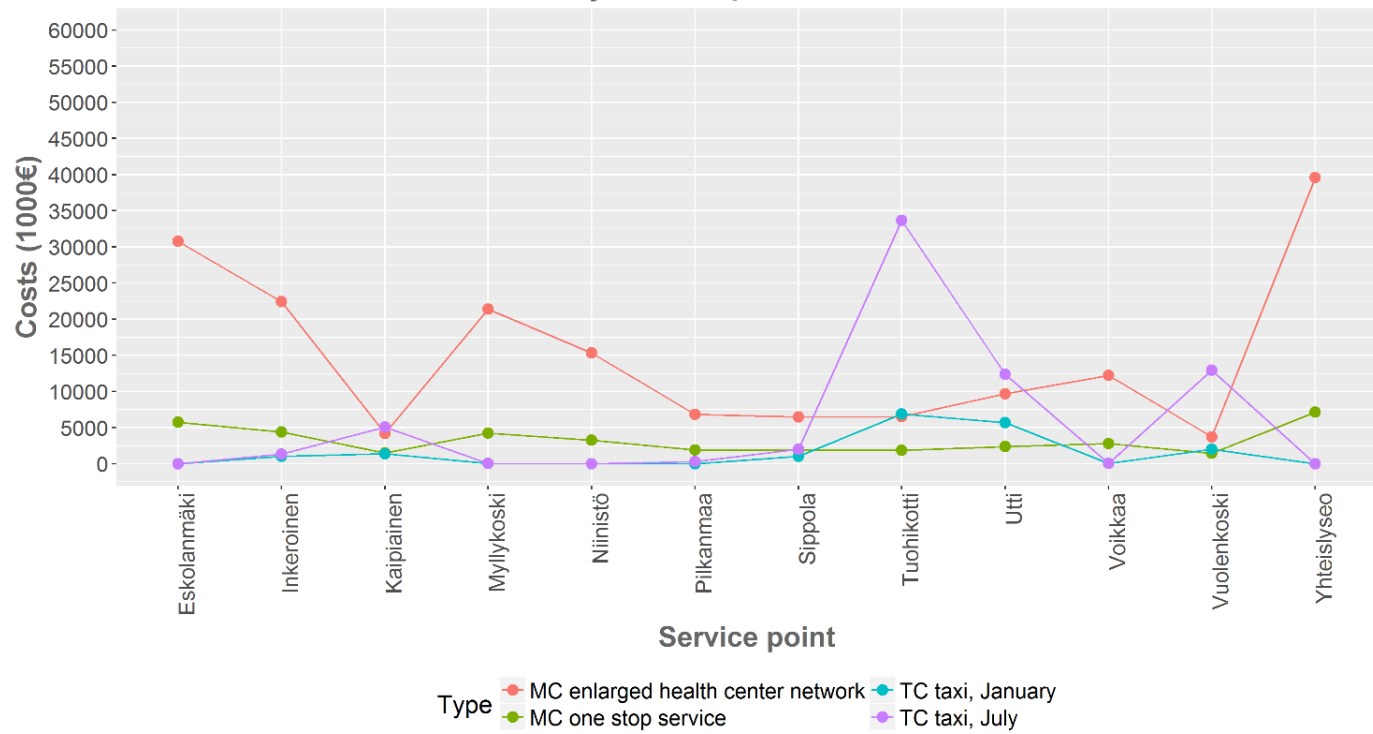

Travel and maintenance costs by service points

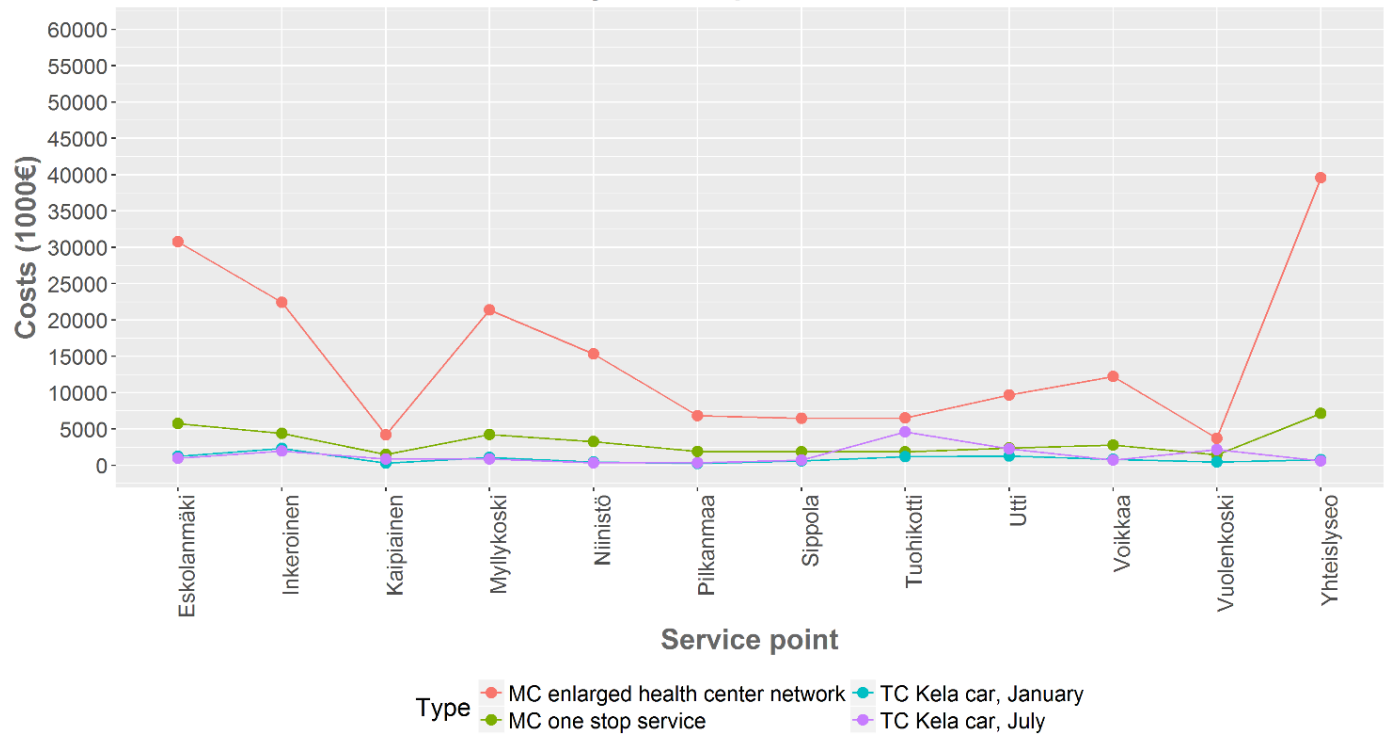

Fig 6. Maintenance and travel costs for health centres in January and July. (Abbreviations: MC = Maintenance cost, $T C=$ Travel costs). 

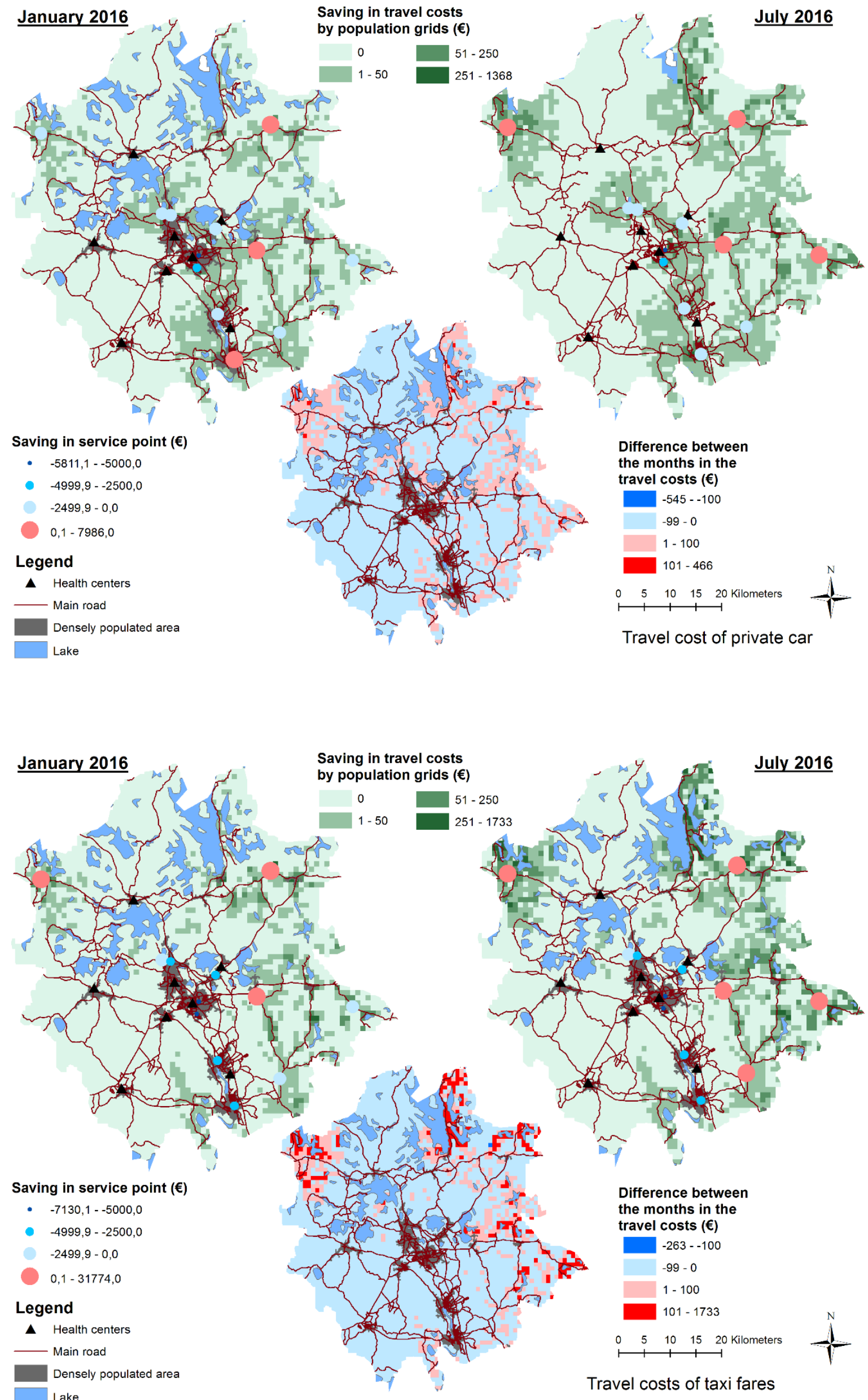


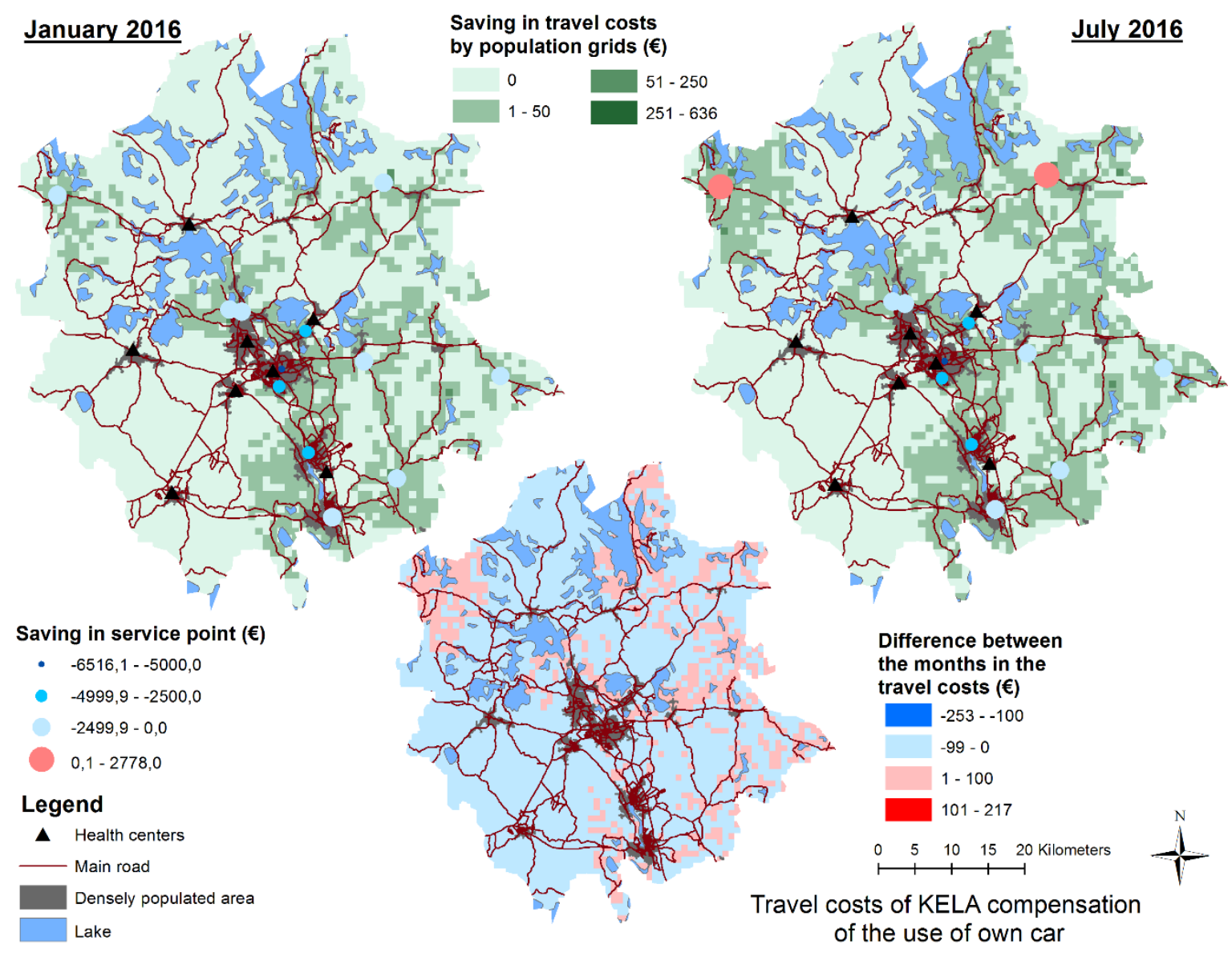

Fig 7. The savings generated by the multi-service points in travel costs by service points and population grids in January and July.

\section{Conclusions and discussion}

Multi-local living offers new opportunities in the provision of health services in rural areas, if it is included in the planning of services and seen as a resource for developing rural areas. The results of this research showed that regular visits and stays by people moving to rural areas for their leisure increase the profitability of the local health services. In January, the population of the rural areas will correspond to the permanent settlement described in the population register statistics, but in July, the average population in the study area was considerably higher than the population in January. Thus, the population in January did not represent the real number of people in the rural areas.

Despite the strong growth in the average population, the demand for health services did not increase even in July sufficiently for it to be cost-effective to open permanent health centres in the rural areas. The maintenance costs became so high that the savings in travel costs were not sufficient to compensate the growing maintenance costs of health services in the health centres. Therefore, the starting point in rural health services must be in multi-service points with lower maintenance costs or in mobile services which are able to adapt themselves more flexibly to seasonal variation in the demand for health services at different times of the year.

The calculation that was made in the study showed that because of the special conditions of the rural areas compared to urban areas and the strong seasonal variation in population, there is a need for planning which emphasizes local conditions. The areas differ from each other in regard to their population structure and density, locations and the existing services, which affect the place-specific costs for the provision of services. In respect to these factors, the rural areas have their own challenges, which have been noted in earlier studies to affect the cost efficiency of service provision in rural areas (Antikainen et al. 2016). The organization of health services 
and cost efficiency in the differentiated areas require services solutions in the provision of health care that are locally tailored and have been optimized spatially.

The differences shown in the calculation methods in the maintenance costs and travel costs illustrate that the provision of health services for rural areas is dependent on the method for calculating travel costs. If the travel costs are determined using the operating costs of the private car, it could be profitable in the study area to decentralize the provision of health services especially in July. If the calculation of travel costs is based on the taxi compensations paid by Kela, the incentives increase to decentralize service provision in addition to July and also in January, adopting the multi-service point model due to the rising travel costs. If the compensation of travel costs in turn is based on the cheapest compensation for the use of the customer's private car paid by Kela, there will be incentives for the decentralization of services via multi-service points only in July. Irrespective of the calculation method of travel costs, the results show that the decentralized service provision models require new methods.

This study is based methodically on the geographic information system (GIS). The results showed their usefulness when an attempt is being made to understand the role of multiple residence and the different local properties of the rural areas in the planning and provision of health services. The finding of economic incentives requires exact location information and spatial optimization when the decentralized service network is being planned. Without the spatial optimization, the economic benefits of the decentralization of services are not found.

On the other hand, the weaknesses of this study relate to the research data and the generalizations made on the basis of average population and the demand for health services. These shortcomings weaken the reliability of the calculation, but a more exact study database cannot be obtained at the moment. Also, the missing labour costs weaken the authenticity of the cost accounting. The calculation model that was used here was imprecise for these reasons but, however, it illustrated the challenges that increasing multiple residence brings to the singleresidence structured society. At the core of the multiple residence is mobility which increases the profitability of the provision of health services in rural areas and thus challenges the present health care planning which is based on the registered population statistics.

Because of the shortcomings related to the data, the study results can be considered mainly indicative. However, attention must be paid to the fact that despite the shortcomings of the data, the results throw light on the possibilities and challenges to the planning of health services presented by people's increasing mobility. In particular, the results underline the significance of understanding people's mobility, the differences between areas and of locality in the provision of health services. The rough calculations made showed that if the role of multiple residences becomes more visible than at present in society, it could play a greater role in the development of local communities and service production. The need for new governance models addressing multiple residence will increase if multi-locality increases due to the diminishing meaning of the location of employment, for example. At the same time, the need to separate services from the place of domicile increases significantly, which will require new governance systems, such as for example, official dual domicile in the future. The need for this change in society is emphasized by the fact that service models based on single residence appear ineffective in a multipleresidence structured society.

\section{Acknowledgement}

This work was supported by the ROBUST (Rural-Urban Outlooks: Unlocking Synergies) project, funded by the European Union's Horizon 2020 Research and Innovation Programme (grant agreement No 727988). We wish also to thank the reviewers for their valuable comments. 
[1] Adamiak, C., Pitkänen, K. \& Lehtonen, O. (2016). Seasonal residence and counterurbanization: the role of second homes in population redistribution in Finland. GeoJournal 82(5), 1035-1050. DOI: 10.1007/s10708-016-9727-x.

[2] Adamiak, C., Vepsäläinen, M., Strandell, A., Hiltunen, M., Pitkänen, K., Hall, M., Rinne, J., Hannonen, O., Paloniemi, R. \& Åkerlund, U. (2015). Vapaa-ajan asuminen Suomessa Asukas- ja kuntakyselyn tuloksia vapaa-ajan asumisen nykytilasta ja kehittämistarpeista. Helsinki: Suomen ympäristökeskus.

[3] Amcoff, J. (2006). Rural population growth in Sweden in the 1990s: unexpected reality or spatial-statistical chimera? Population, Space and Place 12(3): 171-185. DOI: $10.1002 / p s p .407$.

[4] Antikainen, J., Honkaniemi, T., Jolkkonen, A., Kahila, P., Kotilainen, A., Kurvinen, A., Lemponen, A., Lundström, N., Luoto, I., Niemi T., Pyykkönen, S., Rehunen, A., Saukkonen, P., Viinamäki, O-P. \& Viinikka, A. (2016). Smart Countryside: Maaseudun palveluiden kehittäminen ja monipuolistaminen digitalisaatiota ja kokeiluja hyödyntämällä. Helsinki: Prime Minister Office.

[5] Dick, E. \& Duchêne-Lacroix, C. (2016). Multi-local living in the Global South and the Global North: differences, convergences and universalities of an underestimated phenomenon. Trialog 116/117(1-2), 4-9.

[6] Dittrich-Wesbuer, A., Kramer, C., Duchêne-Lacroix, C. \& Rumpolt, P. (2015). Multi-local living arrangements: Approaches to quantification in German language official statistics and surveys. Tijdschrift voor Economische en Sociale Geografie 106(4): 409-424. DOI: $10.1111 /$ tesg.12160.

[7] Farstad, M. (2013). Local residents' valuation of second home owners' presence in a sparsely inhabited area. Scandinavian Journal of Hospitality and Tourism 13(4), 317-331. DOI: 10.1080/15022250.2013.863062.

[8] Hakimi, S. L. (1964). Optimum locations of switching centers and the absolute centers and medians of a graph. Operations Research 12(3), 450-459.

[9] Haukkala, T. (2011). Monipaikkaisuus - ilmiö ja tulevaisuus. Sitran selvityksiä 54, Helsinki: SITRA.

[10] Heinonen, S. \& Ruotsalainen, J. (2011). Kestävä monipaikkaisuus: Sitran tulevaisuusklinikan tulokset. University of Turku.

[11] Helminen, V., Ristimäki, M. \& Oinonen, K. (2003). Etätyö ja työmatkat Suomessa. Ympäristöministeriö. Helsinki: Edita Publishing Oy.

[12] Huotari, T., Antikainen, H., Pukkinen, M. \& Rusanen, J. (2012). Synnytyspäivystyksen ja erikoissairaanhoidon palveluiden saavutettavuus. Helsinki: Ministry of Social Affairs and Healt Care.

[13] Huotari, T., Antikainen, H. \& Rusanen, J. (2013). Perusterveydenhuollon ympärivuorokautisten päivystyspisteiden saavutettavuus. Helsinki: Ministry of Social Affairs and Healt Care.

[14] Hyrkkänen, U. \& Vartiainen, M. (2007). Hyvinvoinnin haasteet mobiilissa työssä. Työ ja ihminen 21(2), 160-172.

[15] Immonen, M., Koivuniemi, J., Natunen, S. \& Laasonen, K. (2012). Liikkuvat palvelukonseptit hyvinvointipalvelujärjestelmässä: Ikäihmisten hyvinvointipalvelutarpeet Etelä-Karjalan hajaasutusalueella. Lappeenrannan teknillinen yliopisto.

[16] Knuth, D. E. (1977). A Generalization of Dijkstra's Algorithm. Information Processing Letters. 6(1): 1-5. DOI: 10.1016/0020-0190(77)90002-3. 
[17] Kotavaara, O., Antikainen, H. \& Rusanen, J. (2011). Population change and accessibility by road and rail networks: GIS and statistical approach to Finland 1970-2007. Journal of Transport Geography 19(4): 926-935. DOI: 10.1016/j.jtrangeo.2010.10.013.

[18] Kotavaara, O., Hakkarainen, T., Huotari, T., Keistinen, T. \& Rusanen, J. (2015). Mapping Opportunities for Enhancing Effectiveness of Health Care System by GIS Based Accessibility Analysis: Locating Core and Support Services within Long Distances in Northern Finland. In Gartner, G. \& Haosheng, H. eds., Proceedings of the 1st ICA European Symposium on Cartography (pp. 76-91). Vienna University of Technology.

[19] Kwan, M-P. (1998). Space-time and integral measures of individual accessibility: A comparative analysis using a point-based framework. Geographical Analysis 30, 191-216. DOI: 10.1111/j.1538-4632.1998.tb00396.x.

[20] Leinamo, K. (2010). Yhdeksän hyvää ja kymmenen kaunista. University of Vaasa.

[21] Lehtonen, O. (2015). Paikkaperustaisen aluekehittämisen indeksi. Askelia kohti erilaistavaa aluekehittämistä. Yhteiskuntapolitiikka 80(1), 19-45.

[22] Lehtonen, O. (2017). Digitaalisten terveyspalvelujen mahdollisuudet maaseudulla tapauksena Pohjois-Kymenlaakso. In: Kauronen, M-L., Lehtonen, O., eds, Maaseudun ennaltaehkäisevät terveyspalvelut: nykytila, saavutettavuus ja palvelujen tuottamisen paikkaperustaisuus (pp. 81-106). Kouvola: University of Applied Sciences of Sout-East Finland.

[23] Moseley, M. J. \& Owen, S. (2008). The Future of Services in Rural England: The Drivers of Change and a Scenario for 2015. Progress in Planning, 69(3), 93-130. DOI: 10.1016/j.progress.2007.12.002.

[24] Moseley, M. J., Parker, G. \& Wragg, A. (2004). Multi-Service Outlets in Rural England: The Co-location of Disparate Services. Planning, Practice \& Research, 19(4), 375-391. DOI: 10.1080/0269745052000343226.

[25] Moussa, Y., Mahdanian, A. A., Yu, C., Segal, M., Looper, K. J., Vahia, J. I. \& Rej, S. (2017). Mobile Health Technology in Late-Life Mental Illness: A Focused Literature Review. The American Journal of Geriatric Psychiatry 25(8), 865-872, DOI: 10.1016/j.jagp.2017.04.003.

[26] Muilu, T. \& Rusanen, J. (2003). Rural young people in regional development - the case of Finland in 1970-2000. Journal of Rural Studies 19(3), 295-307. DOI: 10.1016/S07430167(03)00003-2.

[27] Müller, D. K. (2002). Second Home Ownership and Sustainable Development in Northern Sweden. Tourism and Hospitality Research 3(4), 343-355. DOI: $10.1177 / 146735840200300406$.

[28] Pitkänen, K. (2013). Vapaa-ajan asumisen muutos nostaa esille tarpeen tarkastella asumisen monipaikkaisuutta. Hyvinvointikatsaus 2, 2-6.

[29] Pitkänen, K., Sireni, M., Rannikko, P., Tuulentie, S. \& Hiltunen, M. J. (2017). Temporary mobilities regenerating rural places. Case studies from northern and eastern Finland. The Journal of Rural and Community Development, 12(2/3), 93-113.

[30] Pyykönen, M. \& Lehtonen, O. (2016). Tietoliikenneyhteyksien merkitys maatilojen ja kuntien kehityksessä. Helsinki: Natural Resources Center.

[31] Rannikko, P. (2008). Sivakan metsät avoimina ja suljettuina tiloina. In: Knuuttila, S. \& Rannikko, P., eds., Kylän paikka. Uusia tulkintoja Sivakasta ja Rasimäestä (pp. 25-58). Helsinki: Society of the Finnish Literature.

[32] Rehunen, A., Rantanen, M., Lehtola, I. \& Hiltunen, M. (2012). Palvelujen saavutettavuus muutoksessa - maaseudun vakituisten ja vapaa-ajan asukkaiden palveluympäristön kehityssuunnat ja uudet mahdollisuudet. Helsinki: Ruralia Institute. 
[33] Rissanen, R., Rehunen, A., Kalenoja, H., Ahonen, O., Mäkelä, T., Rantala, J. \& Pöllänen, M. (2013). Alli-kartasto: Suomen aluerakenteen ja liikennejärjestelmän kehityskuvan pohjustus. Helsinki: Ministry of Environment.

[34] Rodriguen, J-P., Comtois, C. \& Slack, B. (2013). The Geography of Transport Systems, $3^{\text {rd }}$ Edition. Routledge, New York.

[35] Schier, M., Schlinzig, T. \& Montaniri, G. (2015a). The Logic of Multi-Local Living Arrangements: Methodological Challenges and the Potential of Qualitative Approaches. Tijdschrift voor Economische en Sociale Geografie 106(4), 425-438. DOI: 10.1111/tesg.12159.

[36] Schier, M., Hilti, N., Schad, H., Tippel, C., Dittrich-Wesbuer, A. \& Monz, A. (2015b). Residential multi-locality studies - the added value of research on families and second homes. Tijdschrift voor Economische en Sociale Geografie 106(4), 439-452. DOI: 10.1111/tesg.12155.

[37] Silm, S. \& Ahas, R. (2010). The seasonal variability of population in Estonian municipalities. Environment and Planning A: Economy and Space 42(10), 2527-2546. DOI: $10.1068 / \mathrm{a} 43139$.

[38] Sireni, M., Halonen, M., Hannonen, O., Hirvonen, T., Jolkkonen, A., Kahila, P., Kattilakoski, M., Kuhmonen, H-M., Kurvinen, A., Lemponen, V., Rautiainen, S., Saukkonen, P., Åström, C. (2017). Maaseutukatsaus 2017. Helsinki: Ministry of Agriculture and Forestry.

[39] Tuorila, H. (2002). Kaupallisten palvelujen tarjonta ja tulevaisuudennäkymät kehityssuunnaltaan erilaisilla paikkakunnilla. Helsinki: Consumer Research Centre.

[40] Wood, G., Hilti, N., Kramer, C. \& Schier, M. (2015). A residential perspective on multi-locality: Editorial. Tijdschrift voor Economische en Sociale Geografie 106(4): 363-377. DOI: 10.1111/tesg.12158.

\section{Other sources}

[41] Digiroad - kansallinen tie- ja katutietojärjestelmä (2016). (Digiroad - A national system of road and city information). Liikennevirasto. Available in: http://www. digiroad.fi/aineisto/fi_Fl/aineisto/.

[42] Heiskanen, K. \& Värtö, R. (2011). Mallu kylillä: esiselvitys liikkuvien palvelujen toiminnasta. Etelä-Karjalan sosiaali- ja terveyspiiri, Lappeenranta.

[43] Hilmo (2017). Hoitoilmoitusjärjestelmä. Terveyden ja hyvinvoinnin laitos. Available in: https://thl.fi/fi/tilastot-ja-data/ohjeet-tietojen-toimittamiseen/hoitoilmoitusjarjestelma-hilmo.

[44] Kela (2017). Matkakorvauksien omavastuu. Available in: http://www.kela.fi/matkakorvausomavastuu.

[45] Liikennevirasto (Transport Agency) (2011). Digiroad - Tietolajien kuvaus - versio 2.2. Available in:

http://www.digiroad.fi/dokumentit/fi_Fl/dokumentit/files/84853505707737499/default/Digiro ad_tietolajien_kuvaus_22.pdf>.

[46] Liikennevirasto (2012). Henkilöliikennetutkimus 2010-2011 - Suomalaisten liikkuminen. Available in:

http://www2.liikennevirasto.fi/julkaisut/pdf3/lr_2012_henkiloliikennetutkimus_web.pdf>.

[47] LVVI (2010). Recreational Use of Forests - Outdoor Recreation Statistics 2010. The Finnish Forest Research Institute (Metla). Available in: http://www.metla.fi/metinfo/monikaytto/lvvi/en/tietoa-ulkoilusta-2010-en.htm.

[48] Ministry of Social Affairs (Sosiaali- ja terveysministeriö) (2017). Digitalisaatio terveyden ja hyvinvoinnin tukena. Sosiaali- ja terveysministeriön digitalisaatiolinjaukset 2025. https://verkkojulkaisut.valtioneuvosto.fi/stm/zine/2/cover 
[49] Mökkibarometri (2016). FCG Finnish Consulting Group Oy. Helsinki: Maa- ja metsätalousministeriö, Saaristoasiain neuvottelukunta. Available in: http://mmm.fi/documents/1410837/1880296/Mokkibarometri+2016/7b69ab48-5859-4b558dc2-5514cdfa6000.

[50] Saaristoasiain neuvottelukunta (2006). Mökkiläiset kuntapalvelujen käyttäjinä. Sisäasiainministeriö, Sisäasianministeriön julkaisu 24/2006. Helsinki.

[51] Suomen virallinen tilasto (SVT) (2013). Rakennukset ja kesämökit 2012. Tilastokeskus, Suomen virallinen tilasto. Available in: http://www.tilastokeskus.fi/til/rakke/2012/rakke_2012_2013-05-24_kat_001_fi.html.

[52] Suomen virallinen tilasto (SVT) (2015). Työvoimatutkimus [verkkojulkaisu]. ISSN=17987830. työllisyys ja työttömyys 2015, 3 Työajat vuonna 2015 . Statistics Finland. Available in: http://www.stat.fi/til/tyti/2015/13/tyti_2015_13_2016-04-12_kat_003_fi.html.

[53] Suomen virallinen tilasto (2017). Paavo: postinumeroalueittain avoin tieto. Available in: http://www.stat.fi/tup/paavo/index.html.

[54] Statistics Finland (2017). Population structure. Available in: http://www.stat.fi/til/vaerak/index.html.

[55] TEM (2013). Työolobarometri.

[56] Veronmaksajat (2016) (Taxpayers). Kilometrikorvaukset 2016 (Kilometre allowances). Available in: https://www.veronmaksajat.fi/Palkka-jaelake/Kilometrikorvaukset/Kilometrikorvaukset-2016/.

[57] Wikström-Koikkalainen, M., Heiskanen, K. \& Uimonen, I. (2014). Mallu kylillä 2 loppuraportti. Etelä-Karjalan sosiaali- ja terveydenhuollon kuntayhtymä.

[58] YTR (2009) (Maaseutupolitiikan yhteistyöryhmä). Maaseutu ja hyvinvoiva Suomi. Maaseutupoliittinen kokonaisohjelma 2009-2013. Maaseutupolitiikan yhteistyöryhmän julkaisuja 5/2009. 